\title{
Generic Ecological Impact Assessments of Alien Species in Norway: A Semi-Quantitative Set of Criteria
}

\author{
Hanno Sandvik ${ }^{1}$, Bernt-Erik Sæther ${ }^{1}$, Tomas Holmern ${ }^{1 *}$, \\ Jarle Tufto ${ }^{2}$, Steinar Engen ${ }^{2}$, and Helen E. Roy ${ }^{3}$
}

1 Centre for Conservation Biology, Department of Biology, Norwegian University of Science and Technology, 7491 Trondheim, Norway

2 Centre for Conservation Biology, Department of Mathematical Sciences, Norwegian University of Science and Technology, 7491 Trondheim, Norway

3 Biological Records Centre, NERC Centre for Ecology \& Hydrology, Crowmarsh Gifford, OX10 8BB, U.K.

* Current address: Norwegian Directorate for Nature Management, 7485 Trondheim, Norway

\begin{abstract}
The ecological impact assessment scheme that has been developed to classify alien species in Norway is presented. The underlying set of criteria enables a generic and semi-quantitative impact assessment of alien species. The criteria produce a classification of alien species that is testable, transparent and easily adjustable to novel evidence or environmental change. This gives a high scientific and political legitimacy to the end product and enables an effective prioritization of management efforts, while at the same time paying attention to the precautionary principle. The criteria chosen are applicable to all species regardless of taxonomic position. This makes the assessment scheme comparable to the Red List criteria used to classify threatened species.

The impact of alien species is expressed along two independent axes, one measuring invasion potential, the other ecological effects. Using this two-dimensional approach, the categorization captures the ecological impact of alien species, which is the product rather than the sum of spread and effect. Invasion potential is assessed using three criteria, including expected population lifetime and expansion rate. Ecological effects are evaluated using six criteria, including interactions with native species, changes in landscape types, and the potential to transmit genes or parasites. Effects on threatened species or landscape types receive greater weightings.
\end{abstract}

\section{Keywords}

Black List criteria, ecological effect, invasion potential, non-native species, quantitative risk assessment, risk classification

(C) Springer 2012.

Please note: this is the authors' version of the work. It may differ in some minor details from the final article, which will be published in Biodiversity and Conservation by Springer-Verlag. The final publication is available at www.springerlink.com and has the digital object identifier (DOI) 10.1007/s10531-012-0394-Z. Please cite the article as:

"Sandvik H, Sæther B-E, Holmern T, Tufto J, Engen S, Roy HE (in press) Generic ecological impact assessments of alien species in Norway: a semiquantitative set of criteria. Biodivers Conserv, doi:10.1007/s10531-012-0394-z" 


\section{Introduction}

Alien species represent an important current threat against biodiversity, among other things by competing with, preying upon, parasitising, and hybridising with native plant and animal species (Mack et al. 2000; Simberloff 2005). Where rare or keystone species are affected by such adverse interactions (Dextrase and Mandrak 2006; Butchard 2008), or where important landscape elements become altered (Baiser et al. 2008; Higgins and Vander Zanden 2010), alien species may change important ecosystem characteristics (Ehrenfeld 2010), including ecosystem services important to humans (Pejchar and Mooney 2009). For these reasons, coupled with the costs of managing established populations, alien species can also have enormous economic effects (Pimentel et al. 2005; CEU 2009; Vilà et al. 2010).

Accurate risk assessment is an essential precondition for successful management, and is likely to be economically advantageous (Keller et al. 2007). Management of threatened species has been greatly facilitated by the development of generic and quantitative Red List criteria (IUCN 2001), which have been adopted to assemble both international and national Red Lists. Quantitative risk assessment is increasingly applied in conservation biology, e.g. in the form of population viability analyses (Beissinger and McCollough 2002) for the assessment of species' vulnerability to extinction within specified time frames (Mace and Lande 1991). Quantitative risk assessments have a number of advantages over qualitative ones (Vose 2008) because of reduced influence of subjective judgments (Burgman 2002; McCarthy et al. 2004), increased transparency and repeatability (Mrosovsky 1997), and standardised treatment of uncertainty (Stone et al. 1994).

So far, no set of criteria similar to the Red List has been developed for the classification of alien species. At the international and regional level as well as among countries, there is a huge variation in how (and, indeed, whether) the risks posed by alien species are assessed (e.g., WTO 1994; Pheloung et al. 1999; USDA 2000; CFIA 2001; FAO 2004; Baker et al. 2005; Weber et al. 2005; Gederaas et al. 2007; Bomford 2008; Essl et al. 2008; Invasive Species Ireland 2008; Branquart 2009; CEC 2009; Brunel et al. 2010; Kumschick and Nentwig 2010; PLH 2011). These assessment schemes vary widely in method, implementation and taxa covered (reviewed by Verbrugge et al. 2010; Essl et al. 2011), and the majority is based on qualitative methods, even though the need to develop quantitative risk assessments has been recognised (Genovesi and Shine 2004).

Here we present the set of criteria for ecological impact assessment of alien species that underlies the classification of all 2,241 alien species known to occur in Norway (Gederaas et al. in press). It is generic and semi-quantitative, and results in a transparent, testable and dynamic classification of alien species. It is applicable to species already introduced to a country as well as potential future introductions ("next pests").

\section{Set of criteria}

The ecological IMPACT of alien species on the NATIVE fauna and flora is proportional to the area invaded, to densities attained, and to the per-capita effects exerted (Parker et al. 1999; terms in small caps are defined in Box 1). As the area colonised often will be unknown and increasing, area is here replaced by a species's INVASION POTENTIAL. Collapsing density and per-capita effect into one measure of local ecological EFFECT, the impact of alien species can then be described along two axes (Fig. 1). A species with a low score on one of these axes will have a low impact, no matter how high its score on the other axis.

The classification scheme of alien species that we present here follows this two-dimensional approach by determining the placement of alien species along the two axes of Fig. 1 using a total of nine criteria. These criteria are explained below. The placement in the two-dimensional impact area determines the final impact category assigned. Handling of uncertainty and requirements for documentation are outlined towards the end of this section. 


\section{Invasion axis}

The invasion process (subsequent to introduction) can be subdivided into two phases: ESTABLISHMENT and EXPANSION. Based on this insight, alien species are classified along the invasion axis as having "small", "restricted", "moderate" or "high" invasiveness according to their potential to establish and expand, assessed using three criteria (summarised in Table 1):

A. Expected population lifetime. - The higher the expected population lifetime, the higher an alien species scores on the invasion axis. Expected population lifetime is a measure of establishment probability, and is defined as the arithmetic mean time $\bar{T}_{\text {ext }}$ to extinction, obtained by averaging across the probability distribution of possible extinction times. It is a function of initial population size, population growth rate, demographic and environmental variance. Expected population lifetimes can be estimated numerically (see Appendix) or using population viability analyses (Beissinger and McCollough 2002; Morris and Doak 2002). The criterion's rationale is that a species with low expected population lifetimes most likely will go extinct fast, and, even if it doesn't disappear completely, that the remaining population will be small and easily managed. Criterion A can thus be conceived as a mirrored version of the Red List criterion E (IUCN 2001), which is also defined in terms of expected time to extinction. The thresholds chosen for criterion A (see Table 1) make the invasion categories roughly equivalent to the threat categories of the Red List: a small/ restricted/moderate potential for establishment is comparable to a situation where the alien species would be critically endangered (CR) / endangered (EN) / vulnerable (VU), respectively. While population sizes and specific demographic rates cannot easily be compared across different taxa, expected population size is an integrative measure of establishment success that captures the demographic characteristics of a population in a currency common to all taxa, and is thus directly comparable.

B. Mean expansion rate. - The higher the expansion rate, the higher an alien species scores on the invasion axis. Expansion is defined as any increase in a species's area of occupancy (AOO) or extent of occurrence (EOO), irrespective of the pathways and vectors involved. In other words, expansion not only covers self-movement of individual organisms and dispersal (through animals, water, wind, or other means) but also anthropogenic transport and separate introductions (intentional or otherwise). Expansion rate is then modelled as the mean speed $\bar{v}$ of an actual or assumed invasion front, using all observations of the species. While this broad definition of expansion potentially overestimates the natural rates of narrow-sense spread due to dispersal alone, what is relevant for the risk assessment of alien species is an estimate of the expected speed with which the species has reached and will reach previously uncolonised areas. If the expansion of the species is due to many separate introductions (e.g., because it is a popular garden plant), this is a non-random effect of the species' biological characteristics, and should be incorporated into estimates of expansion. The thresholds chosen (cf. Table 1) are defined with the assumption that Norway is the spatial entity of concern. Other regions, or for instance application of the criteria to lower administrative units such as counties, may require different thresholds.

C. Projected maximum area of landscape types occupied. - This criterion measures the proportion of the EOO of the LANDSCAPE TYPES affected that will be colonised by the alien species within 50 years. Criterion $\mathrm{C}$ is invoked if this proportion exceeds certain threshold values for at least one landscape type (Table 1). It will be overridden by criteria A or B under many conditions, but was included because it may be potentially important for relatively rare landscape types. The rationale is that it is conceivable that a rather rare landscape is invaded by an alien species that nonetheless evades the other invasion criteria because it does not occur in other landscapes and invades slowly. Such a species may be a severe threat for this specific landscape type, and should be classified as having a high impact, even if its expected population lifetime and expansion rate are not especially high. The placement of an alien species on the invasion axis is determined by the invasion potential categories obtained using criteria $\mathrm{A}-\mathrm{C}$. The invasion potential can be no less than the category reached by crite- 
rion C. However, the two highest invasion potential categories can be attained by criteria A or B only if the other criterion (B or A, respectively), too, reaches at least the invasion potential immediately below (see Table 1). If this additional condition is not met, the invasion category is defined to be restricted rather than moderate, or moderate rather than high. The rationale for this procedure is that invasion potential is the product of establishment and expansion, i.e. a high expansion rate or a high expected population lifetime are not per se sufficient for an alien species to invade large areas of native landscape: few isolated populations do not constitute an invasion, even if they have a high expected population lifetime. Likewise, local populations that go extinct within a few years have a small invasion potential, even if the rate of spread or introduction is high.

\section{Effect axis}

Alien species are classified along the effect axis as having "no known", "minor", "medium" or "major effects" according to their influence on native biota - both on the species and the landscape level assessed using six criteria (summarised in Table 2). The more strongly and extensively an alien species INTERACTS with native species (criteria D and E); the larger the changes in landscape structure it brings about (criteria $\mathrm{F}$ and $\mathrm{G}$ ); and the higher the risk that it transmits genes or pathogens to native species (criteria $\mathrm{H}$ and I) - the higher it scores on the effect axis. Effects are considered if they are documented to have occurred, or if they are likely to occur within 50 years or three generations (whichever is the longer period; although not more than 300 years).

Effects on native species are assessed in terms of the likely reduction in native species' long-term population growth rate $(r)$, carrying capacity $(K)$, AOO or EOO. In principle, these reductions lend themselves to quantitative or numeric analysis, too (e.g., Laska and Wootton 1998). However, such quantification of effects is difficult in practice because it requires extensive long-term study (Doak et al. 2008; Novak and Wootton 2008), and is, therefore, not suggested here. Instead, a larger degree of subjective judgment is allowed for than on the invasion axis. An effect is thus referred to as unlikely if it is not documented or likely that the alien species enters into any negative interactions with native species. Effects are defined as negligible if negative interactions are likely although the effect is not MEASURABLE. An effect is referred to as weak if it entails a potentially measurable reduction in $r$ or $K$, but without displacing the species in question. Displacement is defined as a potential reduction of a native species' AOO or EOO.

D. Interactions with threatened native species or keystone species. - Any potentially negative ecological interaction between an alien species and at least one THREATENED or KEYSTONE species is automatically classified as no less than an intermediate effect. In case of a measurable reduction in $r, K, \mathrm{AOO}$ or $\mathrm{EOO}$ of at least one threatened or keystone species, the alien species is categorised as having a major impact.

E. Interactions with other native species. - The ecological effect is classified as milder if none of the species affected by the alien species is threatened or a keystone species. Intermediate or major effects are defined as local or regional displacement, respectively.

Effects on landscape structure are assessed in terms of STATE CHANGES in LANDSCAPE TYPES brought about by the alien species (Halvorsen et al. 2009). Examples of state changes are eutrophication, changes in the stratification of vegetation, or major reductions of tree density. Such effects are quantified by estimating the maximum proportion of landscape types' $\mathrm{AOO}$ or EOO that is undergoing significant state change.

F. State change in threatened or rare landscape types. - Any significant state change brought about by an alien species in at least one THREATENED or RARE landscape type is automatically classified as no less than an intermediate effect.

G. State change in other landscape types. - The ecological effect is classified as milder if none of the landscape types undergoing state changes because of the alien species are threatened or rare. 
The final two criteria measure the risks of transmitting genes or parasites.

H. Genetic introgression. - If it is documented or likely that an alien species can transmit genetic material to any native species, it is automatically classified as having an intermediate effect. If at least one of the native species concerned is a threatened or keystone species, introgression is regarded as a major effect.

I. Vector for parasites. - If it is documented or likely that an alien species can transmit parasites, including pathogens such as bacteria or viruses, to any novel native host, it is automatically classified as having an intermediate effect. This is upgraded to a major effect under any of the following two conditions: if the alien species acts as vector for a novel (i.e., alien) parasite, or if any of the novel native hosts is a threatened or a keystone species.

The placement of an alien species on the effect axis is determined by the highest effect category obtained using criteria D-I.

\section{Final impact category}

The two axes with four partial risk categories result in 16 possible combinations of invasion potential and ecological effect (Fig. 1). The placement of alien species within the two-dimensional risk space of Fig. 1 determines their assignment to one out of five final impact categories, the two highest of which constitute the Black List:

1) Severe impact (SE). - These species are actually or potentially ecologically harmful and have the potential for establishment over large areas, i.e. they attain high scores on both axes. They should be the major priority in management of alien species.

2) High impact (HI). - These species combine intermediate scores on one axis with a high score on the other. They have either some or considerable ecological impact, but a restricted ability to invade new environments. Alternatively, the species have a high invasion potential, but only minor ecological effects are documented. The distribution and local population dynamics of the species in this category should be regularly monitored.

3) Potentially high impact (PH). - These species achieve the highest risk score on one axis but the lowest on the other: they have either major ecological effects but a small invasion potential; or high potential for expansion but no known ecological effects. These species, although actually having a low impact, have the potential to increase their impact potential either through evolutionary change or though unforeseen ecological interactions. They should, therefore, be surveyed in order to make sure that changes in impact potential are noticed early.

4) Low impact (LO). - According to the documentation available, these species have a low ecological impact and do not constitute a priority for management.

5) No known impact (NK). - Species in this category are of least concern. If desirable, the exact position in the two-dimensional impact space can be added to the abbreviations, e.g. as HI:4,2 or HI:2,3 (denoting a high-impact species with a high invasion potential and minor ecological effects, or with a restricted invasion potential and medium ecological effects, respectively; cf. Fig. 1). This may be especially relevant for species with a potentially high impact, where $\mathbf{P H}: \mathbf{1}, \mathbf{4}$ and PH:4,1 species will have rather different characteristics. It may also be useful to supply as additional information the criteria according to which a species was categorised as it was: a HI:2(b),4(e) species was classified as high-impact because of its threat to native species and its invasion rate; while a HI:2(a),4(h) species obtained the same impact category because of its hybridization with threatened native species and its expected population lifetime. 


\section{Assessment of uncertainty}

The classification scheme presented here does not contain a "data deficiency" category, such as DD in the Red List. The experts carrying out the assessment are encouraged to use the data available in order to obtain an estimate of an alien species's invasion potential and ecological risk. All estimates contain uncertainty. Even for species with comparatively good data, it is difficult to give precise predictions. To take uncertainty into account, rather than erecting an additional category, one should include the amount of uncertainty in the assessment. This is accomplished by estimating prediction intervals, and by selecting the highest category that is encompassed by the intervals.

Where data are extremely sparse, it is a conceivable situation that an alien species has a high impact, but that this fact is not possible to document (type II error). In contrast to comparable situations in the classification of threatened species, however, this does not pose severe problems in the classification of alien species: data deficiency is most often caused by, or at least correlated with, the rareness of the species concerned, supporting the hypothesis that the species may be in danger of going extinct, but at the same time weakening the assumption that it is invasive. The second distinction from the Red List is that the consequences of erring are not as catastrophic. If a threat against a rare species has been overlooked, the species may be lost ("extinct is forever"). If a threat posed by an alien invasive species has been overlooked, the consequences may be dramatic, but not necessarily irreversible.

A further consideration is that a classification list of alien species should be reliable for the end user. A list where many species have been included as having a "high impact" only because of the absence of evidence to suggest otherwise, is useless and loses its legitimacy. Only species that are documented to have a high impact should be listed as such. If such documentation is pending, this knowledge would have to be included as it accrues, it should not be merely anticipated.

\section{Documentation}

It is a requirement to document that any criterion is met. Documentation at all stages is a crucial part of quantitative assessment (Vose 2008), and a necessary requirement for the transparency and testability of the resulting listing (Mrosovsky 1997). Scientific publications, reports as well as unpublished data are accepted as documentation, as long as the latter are made available by the experts. Documentation also includes reporting the complete input values of models performed, not merely their output.

Ideally, alien species should be identified, classified, and, if required and possible, eradicated as early as possible. This creates the problem that data on the occurrence and performance of the alien species in its new environment often will be scarce. Where data on a given species are not available from the country or region for that it is assessed, data should, in this order, be sought from:

- other regions with comparable ecoclimatic conditions,

- other regions with different ecoclimatic conditions,

- other, preferable closely related, species with comparable ecological and demographic characteristics.

Precautionary principle

Because of the dynamic and potentially enormous threats posed by alien species, any classification scheme should take the precautionary principle into account. However, precaution should not be traded off against the legitimacy of the listing produced, and so any such decision should be based on documented and testable evidence. We have thus applied three principles:

- One Out, All Out. - According to this principle, a species is categorised by selecting the highest risk category of which at least one criterion is met. Criteria used to assess species should not simply be summed, because this may result in an intermediate risk category for species that score extremely high on one criterion but low on others (cf. Makowski and Mittinty 2010). The set of criteria proposed here applies the One Out, All Out principle to the effect axis. To the invasion axis it is applied with some restrictions (see above and Table 1). 
- Future impact. - Alien species may still be in the process of establishing or expanding when they are assessed. Their invasion potential and ecological effects should therefore be based not only on estimates for the current situation, but also incorporate predictable changes in the foreseeable future. The time frame should not be too long either, however, because too long forecasts easily turn speculative. We apply a time frame of 50 years or three generations. Predictable changes include changes in population size, EOO and AOO (all of which can be modelled using population and habitat occupancy models), as well as known age- or frequency-dependent changes in ecological effects.

- Incorporation of uncertainty. - Procedures used in quantitative sets of criteria can produce prediction or confidence intervals (see section Assessment of uncertainty above). This is especially applicable to the criteria at the invasion axis (A-C). Where this is not feasible, experts should use the available evidence to put boundaries for likely estimates given the evidence available. These intervals or boundaries may cover more than one risk category, in which case the highest of these risk categories should be chosen.

\section{Application}

We have tested the classification system by applying it to five example species. The application of the classification scheme not only needs criteria but also ways to model or estimate their values, and so we begin with considerations on the estimation process. Different models and different assumptions result in different estimates of both expected population lifetime and of expansion rate (e.g., Shigesada and Kawasaki 1997; Petrovskii and Li 2006; Hooten and Wikle 2008). The dynamics underlying invasion are affected by a large number of parameters, such as density regulation in space and time, growth rate at low densities, patterns of expansion and demographic and environmental stochasticity (cf. Kot et al. 1996; Neubert et al. 2000; Freckleton et al. 2006; Lewis et al. 2006). The large number of parameters needed in order to provide a good description of the mechanisms of expansion of an alien species in a new environment (e.g., Veit and Lewis 1996) cannot normally be estimated from data on spread alone. Data on local population dynamics, how these co-vary in time, and how individuals spread, are required, too. Very few datasets with such a level of detail are available so far.

In the absence of any universally accepted and robust models to describe invasions, we recommend to base estimates of criterion A and B on rather simple models. In our examples, we have thus estimated expected population lifetime numerically from demographic parameters (current population size $N_{0}$, population growth rate $\lambda$, demographic and environmental variance $\sigma_{\mathrm{d}}^{2}$ and $\sigma_{\mathrm{e}}^{2}$; see Appendix). Expansion rate was estimated based on all individual observations of the species under the assumption of sampling error and no process variance (see Apendix).

\section{Example species}

(i) The horse-chestnut leaf miner (Cameraria ohridella, Gracillariidae, Lepidoptera) is a moth of uncertain geographical origins. The first European observations stem from Macedonia around 1980 (Deschka and Dimić 1986), from where it has spread to large parts of Europe. It reached Sweden and Denmark in 2002 and Finland in 2006 (Buhl et al. 2003), but has not yet been observed in Norway. It spreads primarily through wind, although Finland may have been colonised anthropogenically. Caterpillars infest horse chestnuts (Aesculus hippocastanum) and, to a lesser extent, Aesculus $\times$ carnea, Norway maple (Acer platanoides) and sycamore (Acer pseudoplatanus).

The primary host species is not native to Norway, which limits the potential population size and expected lifetime and expansion rate. Our estimates of expansion rate are based on the large number of systematic observations collected in Great Britain mainly by amateurs (Fig. 2a, b; data provided by Forest Research, UK; it should be noted that our estimates are lower than the ones obtained for 
Germany: 54-330 km per year, Gilbert et al. 2004). Criterion B reaches 4, while A is lower than 3, and so the final invasion category is 3 (Table 3 ; cf. Table 1).

Infested trees do not normally die. No other adverse ecological or abiotic effects have been documented, and although the species may attain locally high densities, it does not dominate in any habitat type (Table 4). This places the horse-chestnut leaf miner in the impact category 3,1, i.e. low impact (Fig. 3).

(ii) The Japanese knotweed (Fallopia japonica, Polygonaceae, Magnoliophyta) is an herbaceous perennial plant that was introduced to Europe from East Asia as a garden plant around 1825 (Jäger 1995). It probably arrived to Norway some decades later, and now occurs widespread in low-altitude habitats close to the coast in the entire southern half of Norway, with several isolated occurrences further north (Fremstad and Elven 1997; Fig. 2c). Japanese knotweed is not known to flower in Northern Europe. It therefore only spreads naturally by means of rhizome growth. However, parts of rhizomes can be spread both in freshwater and seawater, and anthropogenically by means of transported soil.

The estimates of expansion rate obtained by using all Norwegian observations as model input were relatively uncertain, but within the thresholds of invasion potential category 2. Based on the high number of patches occupied throughout the country, it is exceedingly unlikely to go extinct (Table 3 ). Criterion A reaches 4, while B is only 2, and so the final invasion category is 3 (Table 3; cf. Table 1).

The Japanese knotweed has been categorised as a problem species in many parts of Europe. It occurs in dense and large stands and so modifies the structure and diversity of plant societies (Hejda et al. 2009) and is able to outcompete native species by means of light competition (Alberternst 1998), which, in turn, can affect the native fauna. Landscape elements are affected because the species can destabilise river banks (Euler 2011). Even though the species's Norwegian population has not yet occupied river banks to a large extent, there is no doubt that the species can have huge ecological effects (Table 4). This results in a risk classification of Japanese knotweed in category 3,4, which implies a severe impact (Fig. 3).

(iii) The harlequin ladybird (Harmonia axyridis, Coccinellidae, Coleoptera) has been introduced from Asia to North America and Europe as a biocontrol agent (Koch 2003). It has been spreading rapidly and partly explosively since the 1990s (Brown et al. 2008). The first documented observation in Norway was in 2006 on a Thuja tree imported from the Netherlands (Sæthre et al. 2010).

Most observations in Norway so far are isolated geographically and mostly inside or close to houses. It is therefore not entirely certain that the species reproduces in the wild in Norway. This makes the estimates of expected population lifetime rather uncertain. The expansion rate could be estimated with relatively high precision from an extensive dataset from Great Britain (Table 3; Fig. 2d; data provided by the UK Ladybird Survey hosted by the Biological Records Centre within the Centre for Ecology \& Hydrology; similar estimates have been reported from France: 17-38 km per year, Augustin et al. 2009).

Besides foraging on fruits, harlequin ladybirds prey upon other insects and their egg and larvae, including other ladybird species (Ware and Majerus 2008). As an effective intraguild predator, the species has led to population declines in many other species (Pell et al. 2008; Roy et al. 2012). Five of the 54 native ladybird species in Norway are listed as endangered (Kålås et al. 2010). Given the rapid expansion in other regions, replacement of some of these threatened species is an imminent risk (Table 4). This places the harlequin ladybird in the severe-impact category 4,4 (Fig. 3).

(iv) The common minnow (Phoxinus phoxinus, Cyprinidae, Teleostei) is a small shoaling fish that is widely distributed in Europe. It has been native to a few catchment areas in Norway. During the 20th century, it has been spread anthropogenically to previously uncolonised areas, mainly because of its use as live bait, and now occurs in all Norwegian counties (Fig. 2e; Museth et al. 2007).

Due to its many established, high-density populations, the species's expected population lifetime is in the highest category. Preliminary estimates of expansion indicate rates of 17-21 km per year (Table 3).

Lakes to which common minnow has been introduced, have experienced a marked decline in benthic invertebrate diversity through predation (Næstad and Brittain 2010). Recruitment of brown 
trout (Salmo trutta) can be strongly negatively affected by competition with and intraguild predation by introduced common minnow (Borgstrøm et al. 1996), and population declines in brown trout have been documented (Museth et al. 2007). Introduced common minnow has caused parasite infections in snails, mussels and insects (Hartvigsen 1997; Table 4). The resulting impact category is 4,3, i.e. severe impacts (Fig. 3).

(v) The Eurasian collared dove (Streptopelia decaocto, Columbidae, Aves) originates in India, but had reached the Middle East in the 16th century. From there, it spread via the Balkan to Europe, where the colonization started approximately 1930. It reached Norway in 1949 (Fig. 2f).

The estimate of expansion rate derived from the Norwegian observations was rather uncertain, but close to and above the highest threshold. The small size and negative trend of the Norwegian breeding population result in a moderate expected population lifetime (Table 3).

There is some evidence from Europe that indicates competition between the Eurasian collared dove and the turtle dove (S. turtur; Rocha and Hidalgo 2000). At high densities, the species may function as a vector for diseases (Fisher 1953). However, to the best of our knowledge, there have not been identified any detrimental effects of the species in Norway (Table 4). We therefore classify the Eurasian turtle dove as impact category 4,1. It is considered to have a potentially high impact because of its high spread potential (Fig. 3).

\section{Discussion}

The set of criteria presented here enables a generic and semi-quantitative impact assessment of alien species. This guarantees a high scientific and political legitimacy of the end product, while at the same time paying attention to the precautionary principle. In several ways, it is a parallel to the set of criteria used to red-list threatened species (IUCN 2001).

In being generic, the classification scheme is applicable to species of all taxa and in all habitats. Like the Red List, any risk category attached to an alien species should have the same biological meaning, and the same priority for management, irrespective of taxonomic placement. The risk categories should thus be interpretable without the additional information whether the species is, e.g., an insect, grass or fish. The application of the set of criteria to some example species has shown this to be the case (Table 5, Fig. 3): it is applicable to alien species from very different taxa (angiosperms, insects, vertebrates), habitats (terrestrial/aquatic), status (already present / still absent) and origins (alien to the entire country / alien to certain counties), and still allows assessing the risks posed by them in a coherent and comparable way. A comparison with other classification systems of alien species, most of which are purely qualitative and partly taxon-specific, shows the resulting impact categories to be realistic (Table 5). A largescale application with 2,241 real-world alien species has recently been carried out (Gederaas et al. in press). A future evaluation of these assessments may lead to adjustments in certain thresholds or criterion definitions.

The set of criteria is independent of the specific definition of alien species chosen (e.g. IUCN 2000; Pyšek et al. 2004; Webber and Scott 2012), i.e. it is compatible with these different definitions. A number of terms has been proposed for subsets of alien species (e.g., Richardson et al. 2000; Pyšek et al. 2004), which can be seen to correspond roughly to some of the criteria in our classification, such as casual alien species (criterion $\mathrm{A}=1$ ), naturalised alien species $(\mathrm{A} \geq 2$ ), invasive alien species (sensu Richardson et al. 2000, i.e. alien species expanding or having expanded their AOO: B $\geq 2$; sensu IUCN 2000, i.e. harmful alien species: HI $+\mathrm{SE})$ or transformer species $(\mathrm{G} \geq 3)$. With the likely exception of criterion $\mathrm{B}$, the criteria can be used irrespective of the delimitation of the assessment area, which may be nations, subnational administrative divisions or specific landscapes.

In being semi-quantitative, the set of criteria produces a classification of alien species that is repeatable, testable, transparent and easily adjustable to novel evidence or environmental change. Rather than assessing criteria using labels such as "high", "medium" and "low risk", based on an expert judgment of the information available, they are evaluated by means of numeric thresholds. 
While this requires more effort and a greater amount of data than do qualitative assessments, the advantages of quantitative assessments outweigh by far their disadvantages: any interested scientist, stakeholder, organization or lay person can inspect the assessment and evaluate why a species is included in a given risk category. An assessments can easily be checked and either verified or corrected; and the effect of specific assumptions, such as detection rate (Clark et al. 2003; Hooten and Wikle 2008), on the final assessment of a species, can be examined. This ultimately ensures an increased scientific and political legitimacy of the classification. As the management of some alien species may be extremely controversial, having large economic implications, repeatability and transparency is a crucial element for acceptance of any classification.

Novel evidence about the ecology or demography of alien species, but also about environmental conditions (e.g., due to climate change, Mainka and Howard 2010; Huang et al. 2011), may invalidate earlier assessments. In semi-quantitative assessments that are based on dynamical models, one can easily change one or more parameters to examine whether and how this affects the final risk category. In other words, while a semi-quantitative method cannot guarantee that an assessment of a specific alien species is "correct", it enables mistakes or knowledge gaps to be identified and corrected or filled more easily. This adjustability is a further, important advantage of semi-quantitative assessment.

Evolutionary changes in introduced species can affect their establishment and invasion ability as well as their impact on native species. Such rapid evolutionary changes have been documented in a number of species that have been introduced to novel environments (Cox 2004; Lavergne and Molofsky 2007; Whitney and Gabler 2008). Just as evolutionary adaptability, novel ecological interactions cannot be predicted in advance (Doak et al. 2008), especially when indirect interactions are concerned (White et al. 2006). By introducing the impact category "potentially high impact" (PH, Fig. 1), the potential for future evolutionary change and for unforeseen ecological interactions is explicitly taken into account.

The impact of alien species is, in the scheme proposed here, expressed along two axes, one measuring invasion potential, the other ecological effects (see also Branquart 2009; Brunel et al. 2010). These two axes are conceptually independent because invasion potential or effects alone are poor estimators of the risk posed by an alien species. A significant ecological effect on native biota on a local scale does not necessarily imply large ecological impacts at larger geographic scales if the alien species only occurs in restricted areas and has a very low potential to expand. On the other hand, given restricted resources to manage invasive species, it does not seem advisable to prioritise management efforts towards eliminating invasive alien species that have negligible or positive effects on native biota, even if they have, or will, become widespread.

While the assessment of species along each axis is conceptually independent, the resulting scores may not be statistically independent. Population size is an example of a parameter that may influence classification along both axes: propagule pressure is a key parameter influencing establishment and the first phase of spread (Lockwood et al. 2005; Colautti et al. 2006; Blackburn et al. 2009). It is therefore positively correlated with both expected population lifetime and the speed of the invasion front. However, the ecological effects of species may be correlated with their population size, too. Whether or not such statistical dependence between the axes exists is an empirical question, and a promising area for future research (cf. Murphy et al. 2006).

We have based the assessment of effect only on ecological criteria, i.e. the set of criteria does not consider effects of alien species on human health, economics, or aesthetic aspects of landscape structure. Although such considerations may be important when preparing management plans for certain species, we believe that they should not enter into the biological impact assessment as such. Although some classification schemes of alien species consider anthropocentric effects (e.g., Baker et al. 2005; Weber et al. 2005; Bomford 2008; Brunel et al. 2010; Kumschick and Nentwig 2010), the latter cannot unambiguously be expressed on the same continuous scale as ecological effects. Separating the stages of ecological risk assessment and management has the additional advantages of increasing the legitimacy of the end product: the final impact category of a given alien species should inform, but not 
itself be influenced by, alien species management. This is also analogous to the Red List, which is based on purely ecological criteria. By categorising species according to their invasion potential and ecological effects, the classification system also avoids the problem that alien species are sometimes conceived as "bad" simply by virtue of being alien (cf. Goodenough 2010; Moore 2011).

The impact assessment of, and risk communication about, alien species will be greatly improved by a generic and quantitative classification scheme. We hope that the Norwegian set of criteria presented here can act as a step in this direction.

\section{Acknowledgements}

The development of the new set of criteria was solicited and funded by The Norwegian Biodiversity Information Centre (Artsdatabanken). Further funding was provided by the Norwegian Directorate for Nature Management (DN). Valuable input, comments and help came from L Gederaas, S Henriksen, TL Moen, I Salvesen, H Sandmark, S Skjelseth (Artsdatabanken), E Ødegaard (DN), HH Grundt (FlowerPower), M Crawley (Imperial College), H Loeng (Institute of Marine Research), R Andersen (Museum of Natural History and Archaeology at NTNU), R Elven (Natural History Museum at University of Oslo), LT Kristjánsson (Norwegian Directorate of Fisheries), HP Brække (Norwegian Food Safety Authority), BH Øyen (Norwegian Forest and Landscape Institute), T Hofsvang (Norwegian Institute for Agricultural and Environmental Research), JA Kålås, F Ødegaard, OT Sandlund, O Skarpaas (Norwegian Institute for Nature Research), RA Ims (University of Tromsø) and the anonymous reviewers. We thank N Straw at Forest Research (UK) for kindly proyiding observational data.

\section{References}

Alberternst B (1998) Biologie, Ökologie, Verbreitung und Kontrolle von Reynoutria-Sippen in BadenWürttemberg. Culterra 23:1-198

Amiri A, Talebi AA, Zamani AA, Kamali K (2010) Effect of temperature on demographic parameters of the hawthorn red midget moth, Phyllonorycter corylifoliella, on apple. J Insect Sci 10(134):1-12

Augustin S, Guichard S, Heitland W, Freise J, Svatoš A, Gilbert M (2008) Monitoring and dispersal of the invading Gracillariidae Cameraria ohridella. J Appl Entomol 133:58-66

Baiser B, Lockwood JL, La Puma D, Aronson MFJ (2008) A perfect storm: two ecosystem engineers interact to degrade deciduous forests of New Jersey. Biol Invasions 10:785-795

Baker R, Hulme P, Copp GH, Thomas M, Black R, Haysom K (2005) UK non-native organism risk assessment scheme user manual: version 3.3. Great Britain Non-native Species Secretariat, York

Beissinger SR, McCollough DR (eds, 2002) Population viability analysis. University of Chicago Press, Chicago

Blackburn TM, Lockwood JL, Cassey P (2009) Avian invasions: the ecology and evolution of exotic birds. Oxford University Press, Oxford

Bomford M (2008) Risk assessment models for establishment of exotic vertebrates in Australia and New Zealand. Invasive Animals Cooperative Research Centre, Canberra

Borgstrøm R, Brittain JE, Hasle K, Skjølås S, Dokk JG (1996) Reduced recruitment in brown trout Salmo trutta, the role of interactions with the minnow Phoxinus phoxinus. Nord J Freshw Res 72:30-38

Branquart E (2009) Guidelines for environmental impact assessment and list classification of non-native organisms in Belgium: version 2.6. Belgian Forum on Invasive Species, Bruxelles

Brown PMJ, Adriaens T, Bathon H et al. (2008) Harmonia axyridis in Europe: spread and distribution of a nonnative coccinellid. BioControl 53:5-21

Brunel S, Branquart E, Fried G et al. (2010) The EPPO prioritization process for invasive alien plants. Bull OEPP 40:407-422

Buhl O, Falck P, Jørgensen B, Karsholt O, Larsen K, Vilhelmsen F (2003) Fund af småsommerfugle fra Danmark i 2002 (Lepidoptera). Entomol Medd 71:65-76

Burgman MA (2002) Flaws in subjective assessments of ecological risks and means for correcting them. Aust J Environ Manage 8:219-226 
Butchard SHM (2008) Red List indices to measure the sustainability of species use and impacts of invasive alien species. Bird Conserv Int 18(Suppl):S245-S262

CEC (2009) Trinational risk assessment guidelines for aquatic alien invasive species. Commission for Environmental Cooperation, Montréal

CEU (2009) A mid-term assessment of implementing the EU Biodiversity Action Plan and towards an EU strategy on invasive alien species. Council of the European Union, Bruxelles

CFIA (2001) Canadian PHRA rating guidelines. Canadian Food Inspection Agency, Montreal

Clark JS, Lewis M, McLachlan JS, HilleRisLambers J (2003) Estimating population spread: what can we forecast and how well? Ecology 84:1979-1988

Colautti RI, Grigorovich IA, MacIsaac HJ (2006) Propagule pressure: a null model for biological invasions. Biol Invasions 8:1023-1037

Cox GW (2004) Alien species and evolution: the evolutionary ecology of exotic plants, animals, microbes, and interacting native species. Island Press, Washington, D.C.

Deschka G, Dimić N (1986) Cameraria ohridella sp. n. (Lep., Lithocolletidae) aus Mazedonien, Jugoslawien. Acta Entomol Jugosl 22:11-23

Dextrase AJ, Mandrak NE (2006) Impacts of alien invasive species on freshwater fauna at risk in Canada. Biol Invasions 8:13-24

Doak DF, Estes JA, Halpern BS et al. (2008) Understanding and predicting ecological dynamics: are major surprises inevitable? Ecology 89:952-961

Ehrenfeld JG (2010) Ecosystem consequences of biological invasions. Annu Rev Ecol Evol Syst 41:59-80

Essl F, Klingenstein F, Nehring S, Otto C, Rabitsch W, Stöhr O (2008) Schwarze Listen invasiver Arten - ein Instrument zur Risikobewertung für die Naturschutz-Praxis. Nat Landsch 83:418-424

Essl F, Nehring S, Klingenstein F, Milasowszky N, Nowack C, Rabitsch W (2011) Review of risk assessment systems of IAS in Europe and introducing the German-Austrian Black List Information System (GABLIS). J Nat Conserv 19:339-350

Euler T (2011) Der Japanische Staudenknöterich als „Ökosystemingenieur“ in Flussauen. Geogr Rundsch 63(3):59

FAO (2004) Pest risk analysis for quarantine pests including analysis of environmental risks and living modified organisms: ISPM no. 11. Food and Agriculture Organization, Roma

Fisher J (1953) The Collared Turtle Dove in Europe. Br Birds 46:153-181

Freckleton RP, Dowling PM, Dulvy NK (2006) Stochasticity, nonlinearity and instability in biological invasions. In: Cadotte MW, McMahon SM, Fukami T (eds) Conceptual ecology and invasion biology. Springer, Dordrecht, pp 125-146

Fremstad E, Elven R (1997) Fremmede planter i Norge. De store Fallopia-artene. Blyttia 55:3-14

Gederaas L, Salvesen I, Viken A (2007) Norsk svarteliste 2007 - økologiske risikovurderinger av fremmede arter. Artsdatabanken, Trondheim

Gederaas L, Moen TL, Skjelseth S, Hansen L-K (in press) Alien species in Norway: with the Norwegian Black List 2012. Artsdatabanken, Trondheim

Genovesi P, Shine C (2004) European strategy on invasive alien species. Nat Environ Ser 137:1-60

Gilbert M, Grégoire J-C, Freise JF, Heitland W (2004) Long-distance dispersal and human population density allow the prediction of invasive patterns in the horse chestnut leafminer. J Anim Ecol 73:459-468

Goodenough AE (2010) Are the ecological impacts of alien species misrepresented? A review of the "native good, alien bad" philosophy. Community Ecol 11:13-21

Halvorsen R, Andersen T, Blom HH et al. (2009) Naturtyper i Norge - teoretisk grunnlag, prinsipper for inndeling og definisjoner. Artsdatabanken, Trondheim

Hartvigsen R (1997) Spredning av parasitter ved innvandring og/eller introduksjon av nye fiskearter: spredning av ørekyt (Phoxinus phoxinus) til ørretvassdrag. NINA Oppdragsmeld 466:1-14

Hejda M, Pyšek P, Jarosik V (2009) Impact of invasive plants on the species richness, diversity and composition of invaded communities. J Ecol 97:393-403 
Higgins SN, Vander Zanden MJ (2010) What a difference a species makes: a meta-analysis of dreissenid mussel impact on freshwater ecosystems. Ecol Monogr 80:179-196

Hooten MB, Wikle CK (2008) A hierarchical Bayesian non-linear spatio-temporal model for the spread of invasive species with application to the Eurasian Collared-Dove. Environ Ecol Stat 15:59-70

Huang D, Haack RA, Zhang R (2011) Does global warming increase establishment rates of invasive alien species? A centurial time series analysis. PLoS One 6:e24733

Invasive Species Ireland (2008) Invasive Species Ireland risk assessment. National Parks and Wildlife Service, Dublin, and Northern Ireland Environment Agency, Belfast

IUCN (2000) IUCN guidelines for the prevention of biodiversity loss caused by alien invasive species. International Union for the Conservation of Nature, Gland

IUCN (2001) IUCN Red List categories and criteria: version 3.1. International Union for the Conservation of Nature, Gland \& Cambridge

Jäger EJ (1995) Die Gesamtareale von Reynoutria japonica Houtt. und R. sachalinensis (F. Schmidt) Nakai, ihre klimatische Interpretation und Daten zur Ausbreitungsgeschichte. Schrr Vegkd 27:395-403

Keller RP, Lodge DM, Finnoff DC (2007) Risk assessment for invasive species produces net bioeconomic benefits. Proc Natl Acad Sci USA 104:203-207

Koch RL (2003) The multicolored Asian beetle, Harmonia axyridis: a review of its biology, uses in biological control, and non-target impacts. J Insect Sci 3(32):1-16

Kot M, Lewis MA, van den Driessche P (1996) Dispersal data and the spread of invading organisms. Ecology 77:2027-2042

Kumschick S, Nentwig W (2010) Some alien birds have as severe an impact as the most effectual alien mammals in Europe. Biol Conserv 143:2757-2762

Kålås JA, Viken Å, Henriksen S, Skjelseth S (eds, 2010) Norsk rødliste for arter 2010. Artsdatabanken, Trondheim

Lande R, Sæther B-E, Engen S (2003) Stochastic population dynamics in ecology and conservation. Oxford University Press, Oxford

Lanzoni A, Accinelli G, Bazzocchi GG, Burgio G (2004) Biological traits and life table of the exotic Harmonia axyridis compared with Hippodamia variegata, and Adalia bipunctata (Col., Coccinellidae). J Appl Entomol 128:298-306

Laska MS, Wootton JT (1998) Theoretical concepts and empirical approaches to measuring interaction strength. Ecology 79:461-476

Lavergne S, Molofsky J (2007) Increased genetic variation and evolutionary potential drive the success of an invasive grass. Proc Natl Acad Sci USA 104:3883-3888

Leigh EG Jr (1981) The average lifetime of a population in a varying environment. J Theor Biol 90:213-239

Lewis MA, Neubert MG, Caswell H, Clark JS, Shea K (2006) A guide to calculating discrete-time invasion rates from data. In: Cadotte MW, McMahon SM, Fukami T (eds) Conceptual ecology and invasion biology. Springer, Dordrecht, pp 169-192

Lindgaard A, Henriksen S (eds, 2011) Norsk rødliste for naturtyper 2011. Artsdatabanken, Trondheim

Lockwood JL, Cassey P, Blackburn T (2005) The role of propagule pressure in explaining species invasions. Trends Ecol Evol 20:223-228

Mace GM, Lande R (1991) Assessing extinction threats: toward a reevaluation of IUCN threatened species categories. Conserv Biol 5:148-157

Mack RN, Simberloff D, Lonsdale WM, Evans H, Clout M, Bazzaz FA (2000) Biotic invasions: causes, epidemiology, global consequences, and control. Ecol Appl 10:689-710

Mainka SA, Howard GW (2010) Climate change and invasive species: double jeopardy. Integr Zool 5:102-111

Makowski D, Mittinty MN (2010) Comparison of scoring systems for invasive pests using ROC analysis and Monte Carlo simulations. Risk Anal 30:906-915

McCarthy MA, Keith D, Tietjen J et al. (2004) Comparing predictions of extinction risk using models and subjective judgement. Acta Oecol 26:67-74

Miljøministeriet (2008) Handlingsplan for invasive arter. Miljøministeriet, København 
Moore C (2011) Invasives: classify with care. Science 333:936

Morris WF, Doak DF (2002) Quantitative conservation biology: theory and practice of population viability analysis. Sinauer, Sunderland

Mrosovsky N (1997) IUCN's credibility critically endangered. Nature 389:436

Murphy HT, VanDerWal J, Lovett-Doust L, Lovett-Doust J (2006) Invasiveness in exotic plants: immigration and naturalization in an ecological continuum. In: Cadotte MW, McMahon SM, Fukami T (eds) Conceptual ecology and invasion biology. Springer, Dordrecht, pp 65-105

Museth J, Hesthagen T, Sandlund OT, Thorstad E, Ugedal O (2007) The history of the European minnow in Norway: from harmless species to pest. J Fish Biol 71 (Suppl D):184-195

Neubert MG, Kot M, Lewis MA (2000) Invasion speeds in fluctuating environments. Proc R Soc B 267:1603$1610,2568-2569$

Norton LR, Firbank LG, Scott A, Watkinson AR (2005) Characterising spatial and temporal variation in the finite rate of population increase across the northern range boundary of the annual grass Vulpia fasciculata. Oecologia 144:407-415

Novak M, Wootton JT (2008) Estimating nonlinear interaction strengths: an observation-based method for species-rich food webs. Ecology 89:2083-2089

Næstad F, Brittain JE (2010) Long-term changes in the littoral benthos of a Norwegian subalpine lake following the introduction of the European minnow (Phoxinus phoxinus). Hydrobiologia 642:71-79

Paine RT (1992) Food-web analysis through field measurement of per capita interaction strength. Nature 355:73-75

Parker IM, Simberloff D, Lonsdale WM et al. (1999) Impact: toward a framework for understanding the ecological effects of invaders. Biol Invasions 1:3-19

Pejchar L, Mooney HA (2009) Invasive species, ecosystem services and human well-being. Trends Ecol Evol 24:497-504

Pell JK, Baverstock J, Roy HE, Ware RL, Majerus MEN (2008) Intraguild predation involving Harmonia axyridis: a review of current knowledge and future perspectives. BioControl 53:147-168

Petrovskii SV, Li B-L (2006) Exactly solvable models of biological invasions. Chapman \& Hall, Boca Raton

Pheloung PC, Williams PA, Halloy SR (1999) A weed risk assessment model for use as a biosecurity tool evaluating plant introductions. J Environ Manage 57:239-251

Pimentel D, Zuniga R, Morrison D (2005) Update on the environmental and economic costs associated with alien-invasive species in the United States. Ecol Econ 52:273-288

PLH [European Food Safety Authority Panel on Plant Health] (2011) Guidance on the environmental risk assessment of plant pests. EFSA J 9:2490

Power ME, Tilman D, Estes JA et al. (1996) Challenges in the quest for keystones. BioScience 46:609-620

Pyšek P, Richardson DM, Rejmánek M, Webster GL, Williamson M, Kirschner J (2004) Alien plants in checklists and floras: towards a better communication between taxonomists and ecologists. Taxon 53:131-143

$\mathbf{R}$ development core team (2011) R: a language and environment for statistical computing, version 2.12.2. URL: http://www.r-project.org. R Foundation for Statistical Computing, Wien

Ree V (1994) Tyrkerdue Streptopelia decaocto. In: Gjershaug JO, Thingstad PG, Eldøy S, Byrkjeland S (eds) Norsk fugleatlas: Hekkefuglenes utbredelse og bestandsstatus i Norge. Norsk ornitologisk forening, Klæbu, pp 266-267

Richardson DM, Pyšek P, Rejmánek M, Barbour MG, Panetta FD, West CJ (2000) Naturalization and invasion of alien plants: concepts and definitions. Divers Distrib 6:93-107

Rocha G, Hidalgo SJ (2000) The spread of the Collared Dove Streptopelia decaocto in Europe: colonization patterns in the West of the Iberian Peninsula. Bird Study 49:11-16

Roy HE, Adriaens T, Isaac NJB et al. (2012) Invasive alien predator causes rapid declines of native European ladybirds. Divers Distrib, doi: 10.1111/j.1472-4642.2012.00883.x

Sæthre M-G, Staverløkk A, Hågvar EB (2010) Stowaways in horticultural plants imported from the Netherlands, Germany and Denmark. Norw J Entomol 57:25-35

Shigesada N, Kawasaki K (1997) Biological invasions: theory and practice. Oxford University Press, Oxford 
Simberloff D (2005) Non-native species do threaten the natural environment! J Agric Environ Ethics 18:595-607

Skarpaas O (2012) Levedyktighetsanalyse som grunnlag for risikovurdering av fremmede karplanter. NINA Minirapp 361:1-58

Staverløkk A, Sæthre M-G (2008) Funn av harlekinmarihøna Harmonia axyridis i Norge. Insekt Nytt 33:8-12

Stone ER, Yates JF, Parker AM (1994) Risk communication: absolute versus relative expressions of lowprobability risks. Organ Behav Hum Decis Process 60:387-408

Sutcliffe OL, Thomas CD, Moss D (1996) Spatial synchrony and asynchrony in butterfly population dynamics. J Anim Ecol 65:85-95

Svorkmo-Lundberg M (2006) Tyrkerdue Streptopelia decaocto. In: Svorkmo-Lundberg T, Bakken V, Helberg M, Mork K, Røer JE, Sæbø S (eds) Norsk vinterfuglatlas: Fuglenes utbredelse, bestandsstørrelse og økologi vinterstid. Norsk ornitologisk forening, Trondheim, pp 254-255

Syslo JM, Guy CS, Bigelow PE, Doepke PD, Ertel BD, Koel TM (2011) Response of non-native lake trout (Salvelinus namaycush) to 15 years of harvest in Yellowstone Lake, Yellowstone National Park. Can J Fish Aquat Sci 68:2132-2145

USDA (2000) Guidelines for pathway-initiated pest risk assessment: version 5.02. United States Department of Agriculture, Riverdale

Veit RR, Lewis MA (1996) Dispersal, population growth, and the Allee effect: dynamics of the house finch invasion of eastern North America. Am Nat 148:255-274

Venable DL (2007) Bet hedging in a guild of desert annuals. Ecology 88:1086-1090

Verbrugge LNH, Leuven RSEW, van der Velde G (2010) Evaluation of international risk assessment protocols for exotic species. Rep Environ Sci 352:1-54

Vilà M, Basnou C, Pyšek P et al. (2010) How well do we understand the impacts of alien species on ecosystem services? A pan-European, cross-taxa assessment. Front Ecol Environ 8:135-144

Vose D (2008) Risk analysis: a quantitative guide, 3rd edn. Wiley, Chichester

Waples RS, Jensen DW, McClure M (2010) Eco-evolutionary dynamics: fluctuations in population growth rate reduce effective population size in chinook salmon. Ecology 91:902-914

Ware RL, Majerus MEN (2008) Intraguild predation of immature stages of British and Japanese coccinellids by the invasive ladybird Harmonia axyridis. BioControl 53:169-188

Webber BL, Scott JK (2012) Rapid gobal change: implications for defining natives and aliens. Glob Ecol Biogeogr 21:305-311

Weber E, Köhler B, Gelpke G, Perrenoud A, Gigon A (2005) Schlüssel zur Einteilung von Neophyten in der Schweiz in die Schwarze Liste oder die Watch-Liste. Bot Helv 115:169-173

White EM, Wilson JC, Clarke AR (2006) Biotic indirect effects: a neglected concept in invasion biology. Divers Distrib 12:443 455

Whitney KD, Gabler CA (2008) Rapid evolution in introduced species, "invasive traits" and recipient communities: challenges for predicting invasive potential. Divers Distrib 14:569-580

WTO (1994) Agreement on the application of sanitary and phytosanitary measures. World Trade Organization, Genève 
Box 1 Definitions of terms and concepts used in the set of criteria (small caps indicate terms defined here)

Alien species $\quad$ Several definitions of alien species are available (e.g., IUCN 2000, Pyšek et al. 2004, Webber and Scott 2012). This set of criteria can be used in conjunction with any of these. [For application in Norway, IUCN's definition is used as a basis: "a species, subspecies, or lower taxon occurring outside of its natural range (past or present) and dispersal potential (i.e. outside the range it occupies naturally or could not occupy without direct or indirect introduction or care by humans)". This definition is narrowed down by (a) geographic, (b) temporal, (c) ecological and (d) taxonomic delimitations to species that (a) at the time of introduction had no natural occurrences anywhere in the country as defined by its political borders; (b) were not ESTABLISHED by 1800; (c) have the potential to survive in the wild, i.e. outside artificial or purely anthropogenic habitats; and (d) are multicellular species. Note that the example species considered here were drawn from a wider pool of species in order to test the applicability of the method to other definitions.]

AOO

Effect (ecological) The local negative consequences an alien species has on NATIVE SPECIES or LANDSCAPE TYPES, definable as the product of density and per capita effect. Effects are here envisaged as reductions (MEASURABLE or otherwise) in at least one native species's $r, K$, AOO or EOO or at least one landscape type's AOO or EOO. Neutral or positive (facilitative) effects are not considered.

EOO

Establishment

Expansion

Impact (ecological)

Interaction Extent of occurrence, i.e. the area of the minimum convex polygon delimiting all occurrences of a species or a LANDSCAPE TYPE within the assessment area.

An alien species is regarded as established, if it is represented in the assessment area by at least one population that reproduces sexually or asexually in the wild and has $r \geq 0$ and $K>0$. The establishment probability is 1 - extinction probability.

Active or passive expansion of an alien species's EOO or AOO by any means, vectors and pathways, i.e. including self-movement, dispersal (by animals, wind, water or other means), anthropogenic transport and subsequent introductions (intentional or otherwise).

The cumulative negative consequences an alien species has on NATIVE SPECIES or

LANDSCAPE TYPES over the entire assessment area, definable as the product of area invaded and EFFECT.

Ecological interactions include predator-prey, parasite-host relations, competition and allelopathy, but also indirect effects such as apparent competition and trophic cascades (White et al. 2006). Only interactions that lead to negative EFFECTS on NATIVE SPECIES are considered.

Invasion potential The probability that an alien species ESTABLISHES viable populations and its ability to EXPAND into previously uncolonised areas.

$\boldsymbol{K}$

Carrying capacity, i.e. the population size at which density regulation balances population growth.

Keystone species

A NATIVE SPECIES whose impact on the diversity or geographic or numeric distribution of other native species is "large, and disproportionately large relative to its abundance" (Power et al. 1996), were abundance may be measured in terms of biomass or population size (cf. Paine 1992). 


\begin{tabular}{|ll|}
\hline Landscape type & $\begin{array}{l}\text { A functionally and geomorphologically homogenous part of the natural environment, } \\
\text { including its characteristic biological species, environmental factors and biogeochemi- } \\
\text { cal processes. [For application in Norway, the definition, delimitation and Red List } \\
\text { status of landscape types (there termed nature types) follow Halvorsen et al. (2009) } \\
\text { and Lindgaard and Henriksen (2011).] } \\
\text { Measurable effect } \\
\text { An ecological EFFECT of a magnitude that leads to a biologically significant reduction } \\
\text { in another species's } r \text { or } K \text {. It is not a requirement that the magnitude of the effect is } \\
\text { actually measured in field experiments. Empirical or theoretical evidence from other } \\
\text { countries or comparable species suffices as documentation. } \\
\text { Native species } \\
\text { Any species that is not an ALIEN SPECIES and that occurs and reproduces in the wild } \\
\text { (i.e., outside purely anthropogenic habitats). } \\
\text { The long-term intrinsic population growth rate ( } r=\text { lnd, where } \lambda \text { is the multiplicative } \\
\text { population growth rate per year). } \\
\text { A LANDSCAPE TYPE that is considered near threatened (NT) based on the low number of } \\
\text { existing localities. [For application in Norway, NT according to criteria } 2 \text { or } 3 \text { (Lind- } \\
\text { gaard and Henriksen 2011).] } \\
\text { Temporal change in the state or condition of a LANDSCAPE TYPE. Each landscape type } \\
\text { has a set of possible states that differ in species composition and in biogeochemical } \\
\text { conditions. Such states are often stages in natural succession or the result of natural or } \\
\text { anthropogenic disturbance. A state change due to alien species is regarded as signifi- } \\
\text { cant if it transforms the landscape type to a state that is distinctly different from the one } \\
\text { it would have had or reached in the absence of the alien species. [For application in } \\
\text { Norway, state changes are defined as condition change sensu Halvorsen et al. (2009).] } \\
\text { NATIVE SPECIES or LANDSCAPE TYPES that are critically endangered (CR), endangered } \\
\text { (EN) or vulnerable (VU) according to the relevant Red List. Naturally RARE landscape } \\
\text { types are treated equally to threatened. }\end{array}$ \\
\end{tabular}

Table 1 Categories, criteria, and thresholds used to classify the invasion potential of alien species according to the set of criteria presented here (see text for detailed descriptions of the criteria). The invasion potential category chosen is the highest category of which at least one criterion is met (but see footnote a)

\begin{tabular}{lccc}
\hline Criterion & $\mathbf{A}$ & $\mathbf{B}$ & $\mathbf{C}$ \\
Invasion potential category & $\begin{array}{c}\text { Expected population } \\
\text { lifetime }\end{array}$ & $\begin{array}{c}\text { Mean expansion } \\
\text { rate }\end{array}$ & $\begin{array}{c}\text { Area of landscape } \\
\text { type occupied }\end{array}$ \\
\hline 1: Small invasion potential & $<10 \mathrm{a}$ & $<0.3 \mathrm{~km} / \mathrm{a}$ & $<5 \%$ \\
2: Restricted invasion potential & $\geq 10 \mathrm{a}$ & $\geq 0.3 \mathrm{~km} / \mathbf{a}$ & $\geq 5 \%$ \\
3: Moderate invasion potential & $\geq 50 \mathrm{a} A N D \mathbf{B} \geq \mathbf{2}^{\mathbf{a}}$ & $\geq 10 \mathrm{~km} / \mathbf{a} A N D$ A $\geq \mathbf{2}^{\mathbf{a}}$ & $\geq 10 \%$ \\
4: High invasion potential & $\geq 1000 \mathrm{a} A N D \mathbf{B} \geq \mathbf{3}^{\mathbf{a}}$ & $\geq 30 \mathrm{~km} / \mathbf{a} A N D$ A $\geq \mathbf{3}^{\mathbf{a}}$ & $\geq 20 \%$ \\
\hline
\end{tabular}

a Criteria A and B cannot reach the two highest invasion potential categories (3/4) unless the other criterion (B or A, respectively) meets at least the condition for invasion potential $2 / 3$ (respectively). If the additional condition is not met, the invasion potential category chosen is the one immediately below $(2 / 3$, respectively). 


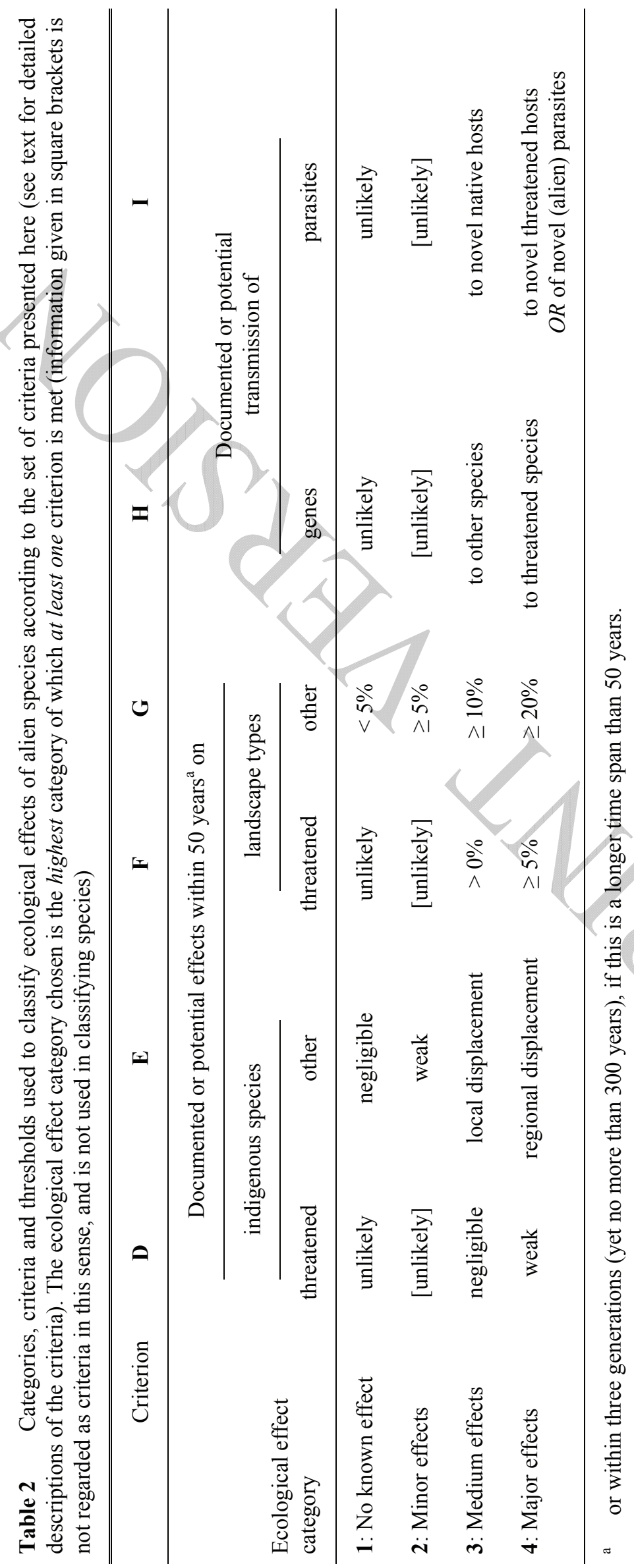




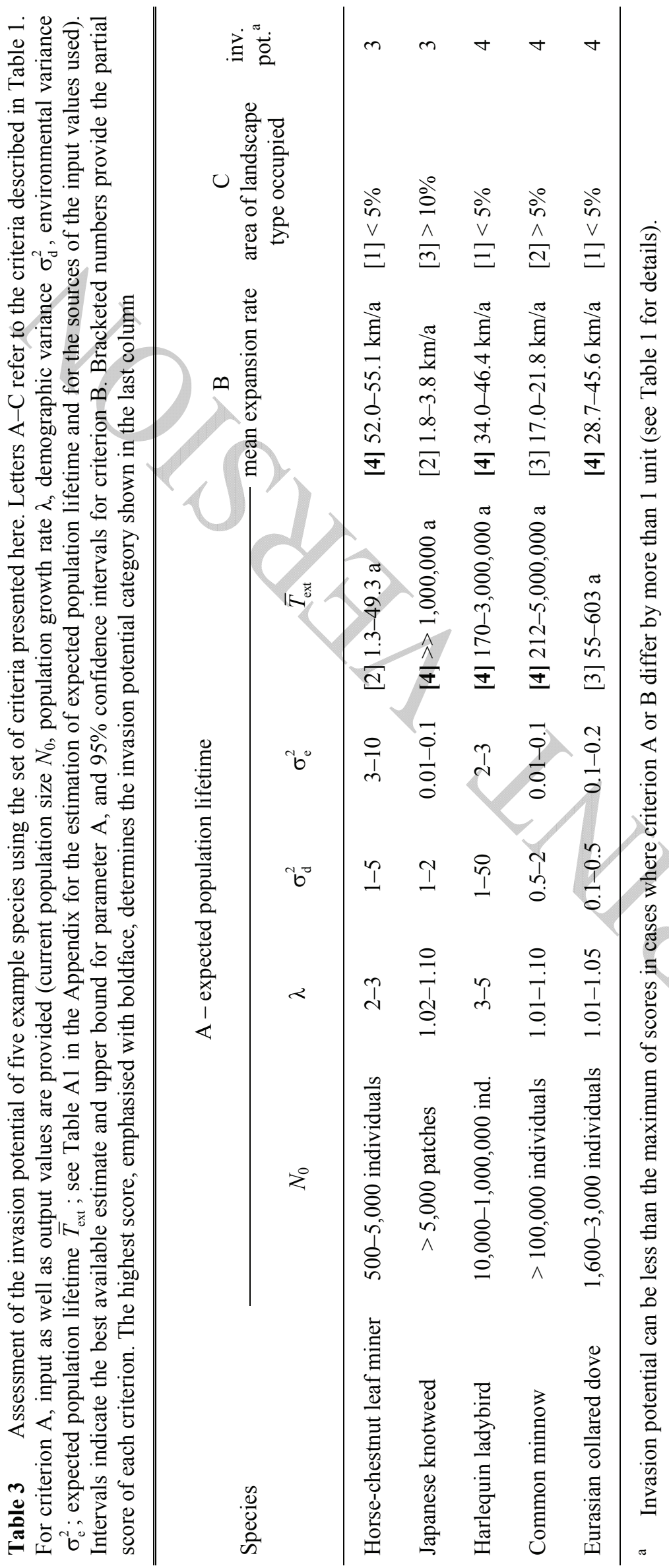


구

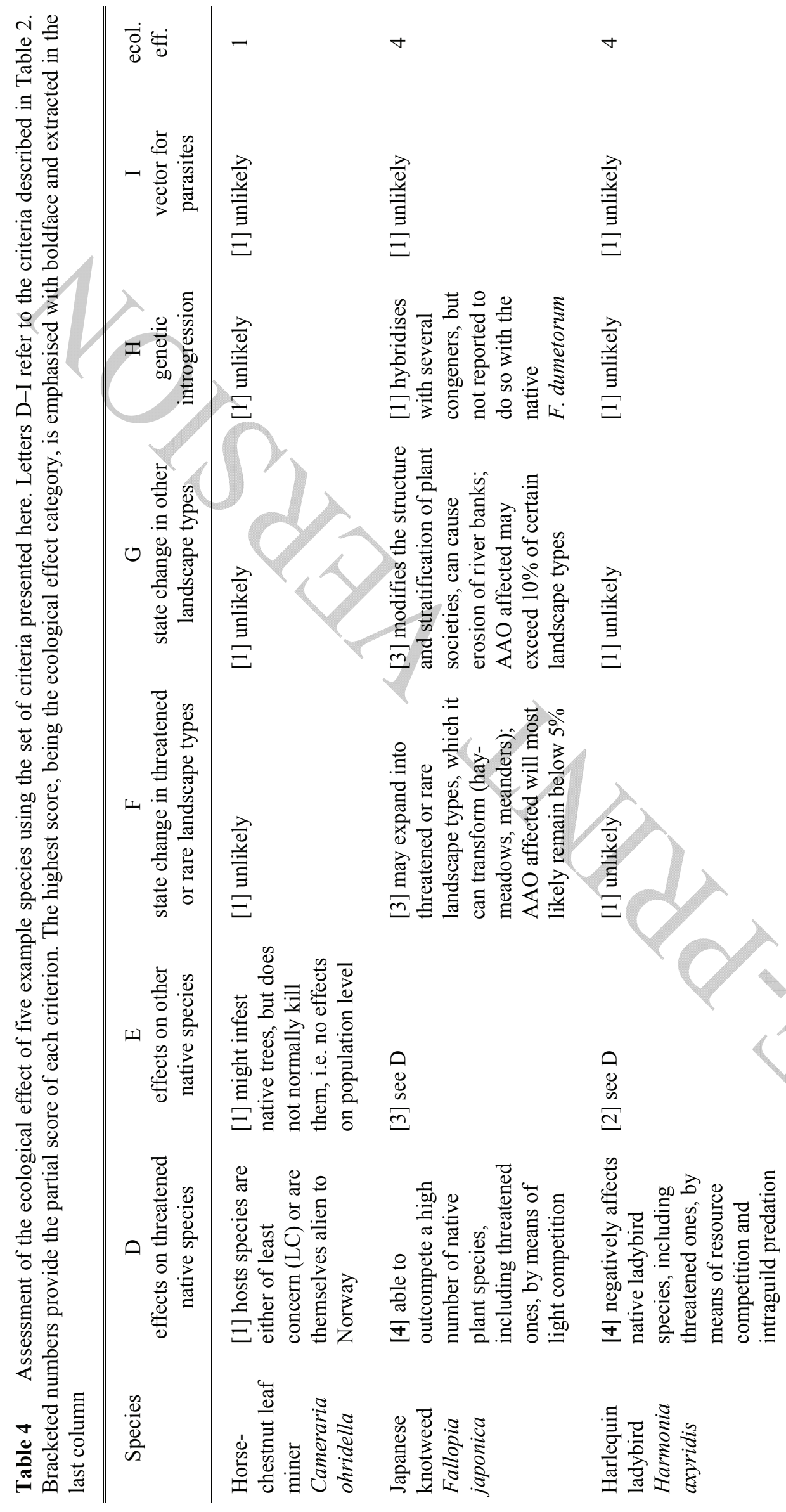


$\bar{v}$

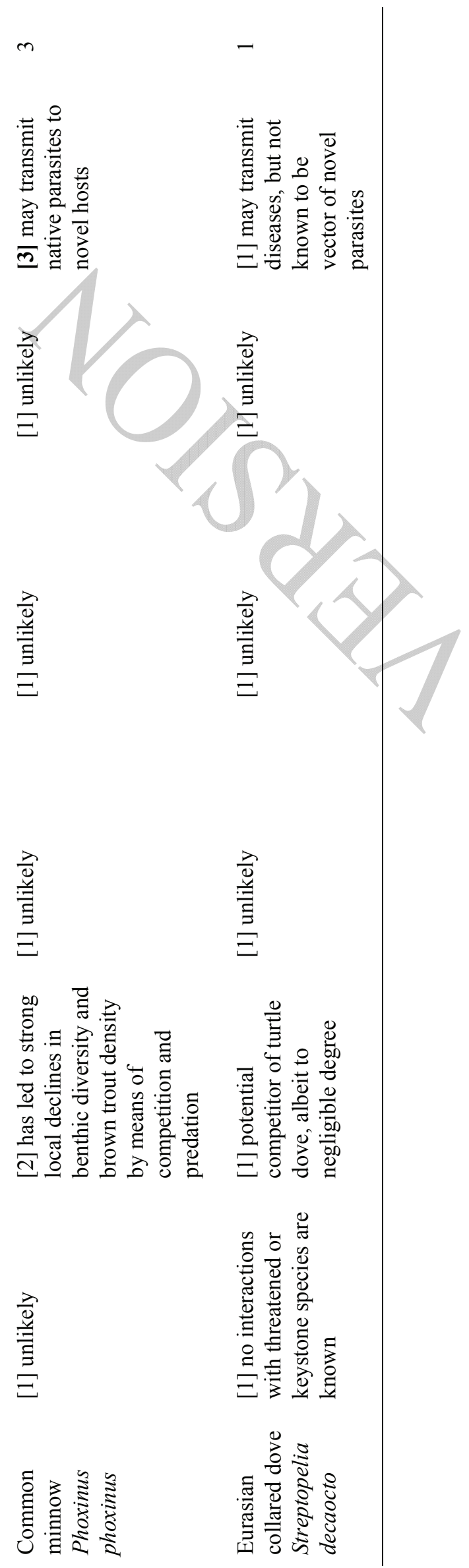


Table 5 Comparison of risk categories given to the five example species by different sets of criteria

\begin{tabular}{|c|c|c|c|c|c|}
\hline $\begin{array}{c}\text { Country/ } \\
\text { organisation }\end{array}$ & $\begin{array}{l}\text { Horse-chestnut } \\
\text { leaf miner }\end{array}$ & $\begin{array}{l}\text { Japanese } \\
\text { knotweed }\end{array}$ & $\begin{array}{l}\text { Harlequin } \\
\text { ladybird }\end{array}$ & $\begin{array}{l}\text { Common } \\
\text { minnow }\end{array}$ & $\begin{array}{c}\text { Eurasian } \\
\text { collared dove }\end{array}$ \\
\hline Norway (this study) ${ }^{\mathrm{a}}$ & LO:3(b),1 & SE:3(a),4(d) & $\mathrm{SE}: 4(\mathrm{ab}), 4(\mathrm{~d})$ & SE:4(a),3(i) & PH:4(b),1 \\
\hline Belgium $^{b}$ & $\mathrm{n} / \mathrm{e}$ & Black List: A3 & Black List: A3 & $\mathrm{n} / \mathrm{e}$ & $\mathrm{n} / \mathrm{e}$ \\
\hline DAISIE $^{c}$ & "worst" & "worst" & "worst" & $\mathrm{n} / \mathrm{e}$ & $\mathrm{n} / \mathrm{e}$ \\
\hline Denmark $^{\mathrm{d}}$ & Black List & Black List & Black List & $\mathrm{n} / \mathrm{e}$ & \\
\hline $\mathrm{EPPO}^{\mathrm{e}}$ & not listed & invasive & $\mathrm{n} / \mathrm{a}$ & $\mathrm{n} / \mathrm{a}$ & $\mathrm{n} / \mathrm{a}$ \\
\hline Great Britain $^{\mathrm{f}}$ & $\mathrm{n} / \mathrm{e}$ & high risk & $\mathrm{n} / \mathrm{e}$ & & $\mathrm{n} / \mathrm{e}$ \\
\hline Ireland $^{\mathrm{g}}$ & $\mathrm{n} / \mathrm{e}$ & high risk: 63 & high risk: 81 & low risk: 1 & low risk: 0 \\
\hline Norway (old) ${ }^{\mathrm{h}}$ & $\mathrm{n} / \mathrm{e}$ & high risk & & risk & $\mathrm{n} / \mathrm{e}$ \\
\hline Switzerland $^{\mathrm{i}}$ & $\mathrm{n} / \mathrm{a}$ & Black List & & & $\mathrm{n} / \mathrm{a}$ \\
\hline
\end{tabular}

Abbreviations:

$\mathrm{n} / \mathrm{a}$, the relevant set of criteria is not applicable to the respective taxon; $\mathrm{n} / \mathrm{e}$, the species has not been evaluated.

Sources:

a note that the preliminary classification arrived at here may not be identical with the finalised Norwegian listing, which had more data at its disposal (Gederaas et al. in press)

b http://ias.biodiversity.be/species/all

c http://www.europe-aliens.org/speciesTheWorst.do [species listed as among "100 of the worst"]

d Miljøministeriet (2008)

e http://www.eppo.int/INVASIVE_PLANTS/ias_plants.htm; http://www.eppo.int/QUARANTINE/Alert_List/deletions.htm [the horse-chestnut leaf miner was added to the EPPO Alert List in 1996 and removed from it in 2001]

f https://secure.fera.defra.gov.uk/nonnativespecies/

g http://invasivespeciesireland.com/toolkit/risk-assessment/

h Gederaas et al. (2007)

i http://www.cps-skew.ch/english/invasive_alien_plants/black_list_watch_list.html 


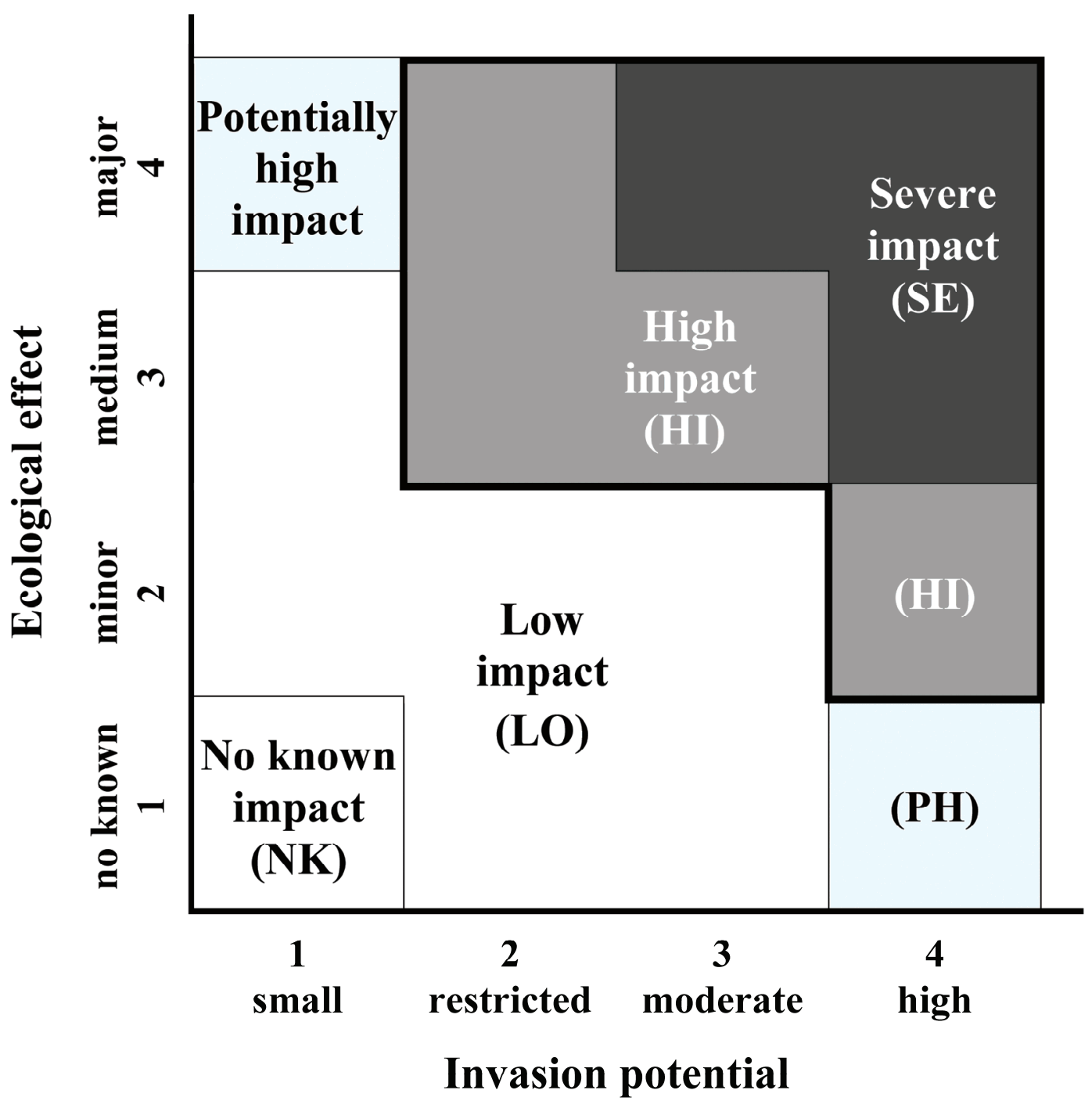

Fig. 1 Classification of alien species according to the set of criteria presented here. Classification follows two different axes, one representing the species' invasion potential, and one their ecological effects. Depending on their placement along both axes, species are categorised as having "no known impact" (NK), "low impact" (LO), "potentially high impact" (PH), "high impact" (HI) or "severe impact" (SE) 

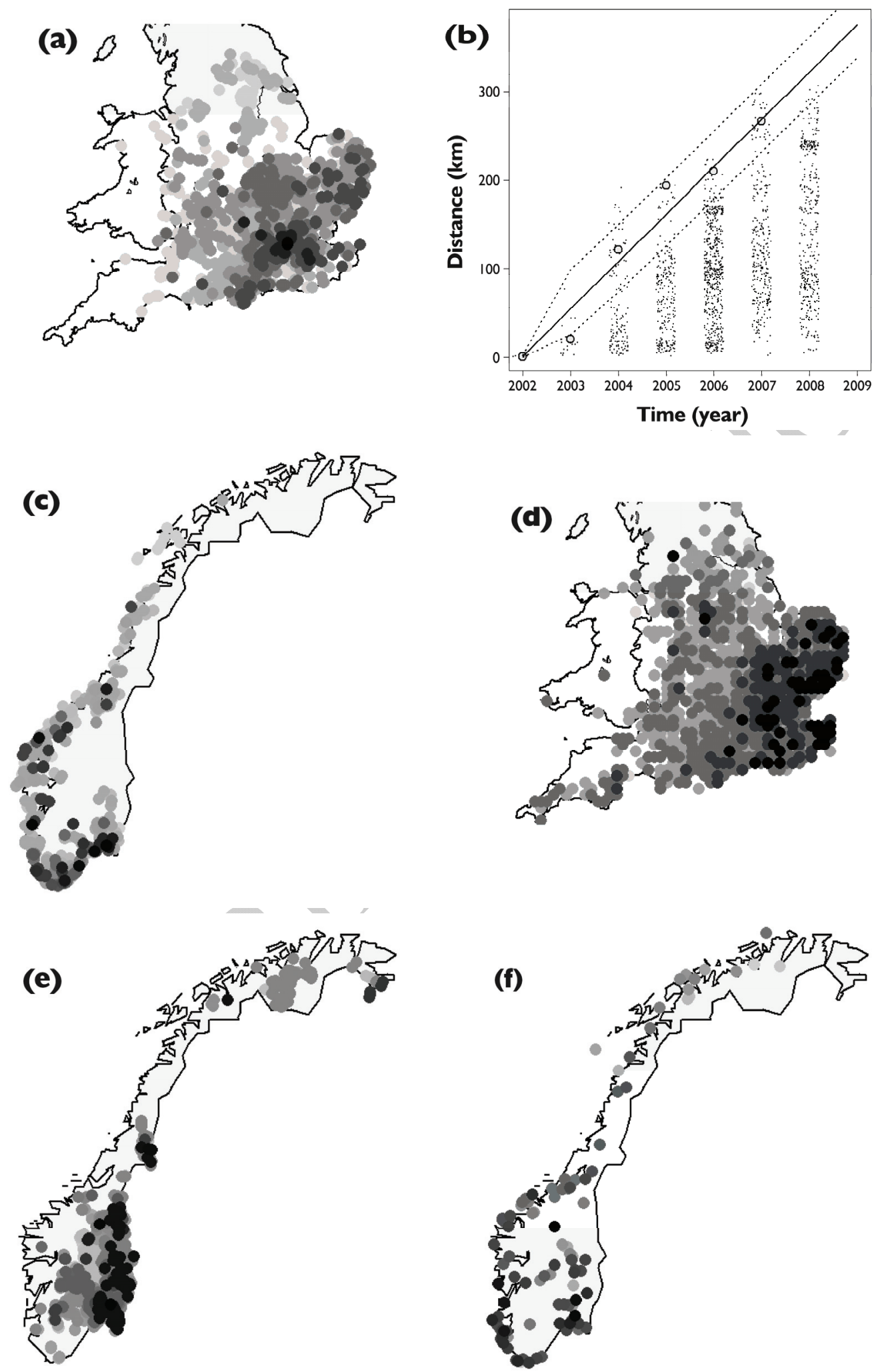

Fig. 2 Spread of (a, b) horse-chestnut leaf miner (2002-2008), (c) Japanese knotweed (1910-2007), (d) harlequin ladybird (2004-2008), (e) common minnow (1900-2008) and (f) Eurasian collared dove (1949-1989) in England (a, b, d) and Norway (c, e, f). (a, c-f) Maps of observations. The earliest observations are shown in black, turning lighter grey towards the present. (b) Linear regression model of spread with regression line and $95 \%$ confidence intervals 


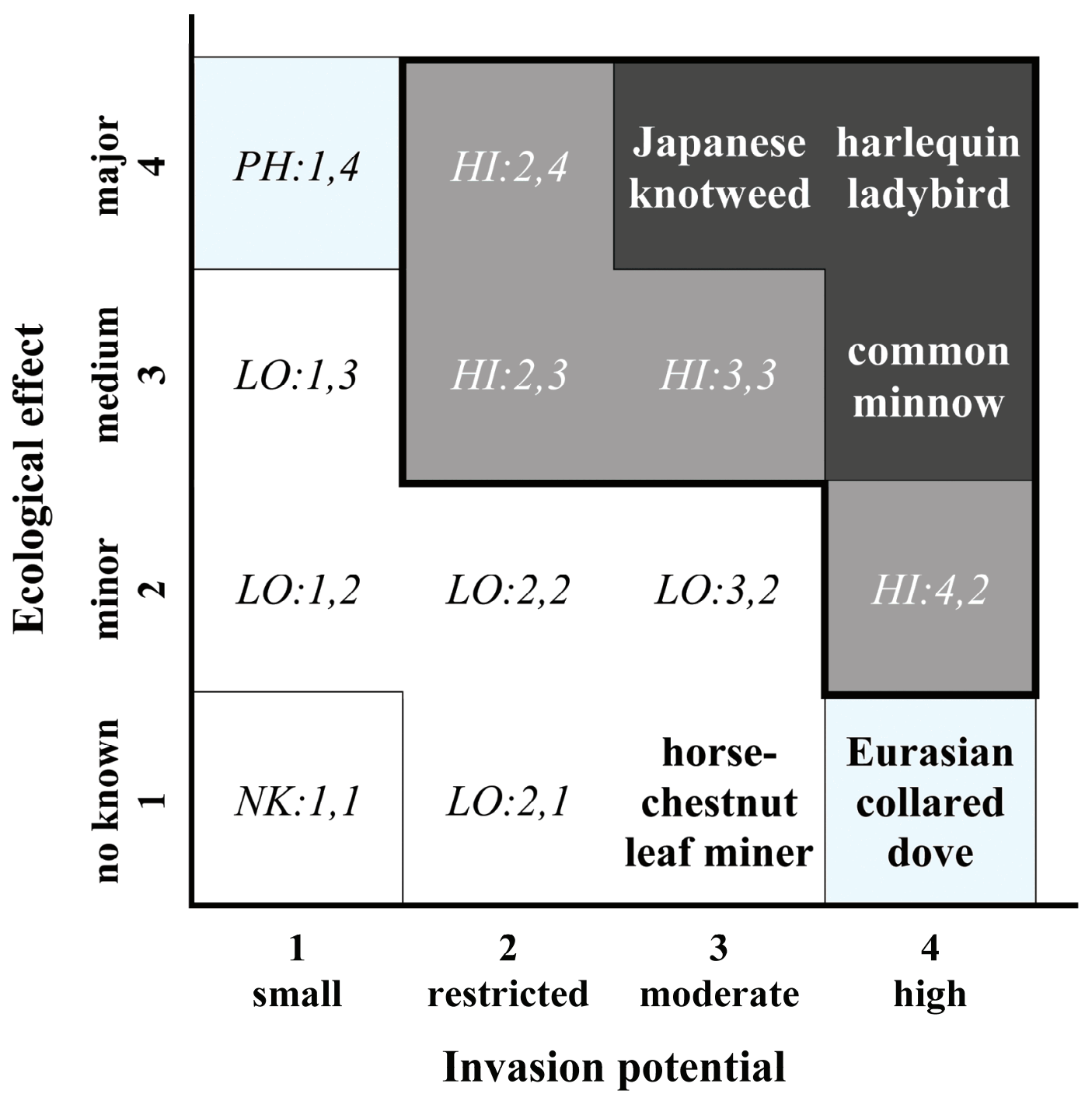

Fig. 3 Classification of five example species according to the qualitative set of criteria presented here 


\section{Appendix: Estimation of expected population lifetime and expansion rate}

Following Leigh (1981; cf. Lande et al. 2003:38-40), expected population lifetime can be estimated as:

$$
\bar{T}_{\mathrm{ext}}=2 \int_{C}^{N_{0}} s(x) \int_{x}^{\infty} \frac{1}{s(N) V(N)} d N d x
$$

where

$$
\begin{aligned}
& s(N)=e^{-2 \int_{C}^{N} M(x) / V(x) d x}, \\
& M(N)=(\lambda-1) N\left[1-\left(\frac{N}{K}\right)^{\theta}\right], \\
& V(N)=\sigma_{\mathrm{d}}^{2} N+\sigma_{\mathrm{e}}^{2} N^{2}+2 \rho \sigma_{\mathrm{e}} \sigma_{\ln K} \frac{\lambda-1}{\bar{K}} N^{3}+\left(e^{\sigma_{\ln K}^{2}}-1\right)\left(\frac{\lambda-1}{\bar{K}}\right)^{2} N^{4},
\end{aligned}
$$

with $C$, quasi-extinction threshold; $K$, carrying capacity; $\lambda=e^{r}$, annual multiplicative population growth rate; $N_{0}$, current population size; $\rho$, correlation between growth rate and environmental noise; $\sigma_{\mathrm{d}}^{2}$, demographic variance; $\sigma_{\mathrm{e}}^{2}$, environmental variance; $\sigma_{\ln K}^{2}$, temporal variance of the carrying capacity; $\theta$, form of the density dependence. An R-script (R development core team 2011) that carries out the estimation of expected population lifetime as described here, is available from the first author (http://www.evol.no/hanno/12/lifetime.htm).

In our analyses, we assumed the quasi-extinction threshold to be 10; carrying capacity to be 100 times current population size; temporal variance of the carrying capacity to be negligible (i.e., $\sigma_{\ln K}^{2}$ $=0$ ); and density regulation to be logistic (i.e., $\theta=1$ ). Simulations have shown that the estimation of expected population lifetime is quite insensitive to variation in these parameters and in demographic variance (Sandvik and Sæther unpubl. data).

Population size was based on reported counts and observations available, accounting for the unreported or undetected fraction of the population (i.e., including levels of uncertainty by dividing known numbers by the estimated or suspected detection rate). Growth rates and variances were based on what is known about the life history of the taxa considered and, were available, on the actual trends of the populations in Norway. In order to obtain intervals, we used the best available estimate as well as a realistic upper limit for each parameter. Table A1 summarises the information used as input to Table 3 including the references consulted.

An alternative way to estimate expected population lifetime is by use of population viability analses. Given estimates on extinction risk within a given timeframe, as used in criterion $\mathrm{E}$ of the international Red List criteria (IUCN 2001), expected population lifetime can be obtained as

$$
\bar{T}_{\text {ext }}=-\Delta t / \ln (1-p) \text {, }
$$

where $p$ is the probability of extinction within time interval $\Delta t$.

Expansion rate was estimated as the speed $\bar{v}$ of an assumed invasion front starting from the position of first observation of the species. Corresponding to our definition of expansion rate, the assumed invasion front was, in turn, inferred using all individual observations of the species, irrepective of how the species might have ended up there (locomotion, dispersal, anthropogenic transport etc.). The speed of the invasion front was then obtained using linear regression under the assumption of sampling error and no process variance. An $\mathbf{R}$-script ( $\mathbf{R}$ development core team 2011) that carries out the estimation of expansion rate as described here, is available from the first author (http://www.evol.no/hanno/12/expans.htm).

The method described may produce unrealistic estimates in cases where an alien species has been introduced a few times at locations that are very far from each other. An alternative definition of expansion rate for such cases would be the sum of the rates estimated from each of the introductions. 
$\hat{\sim}$

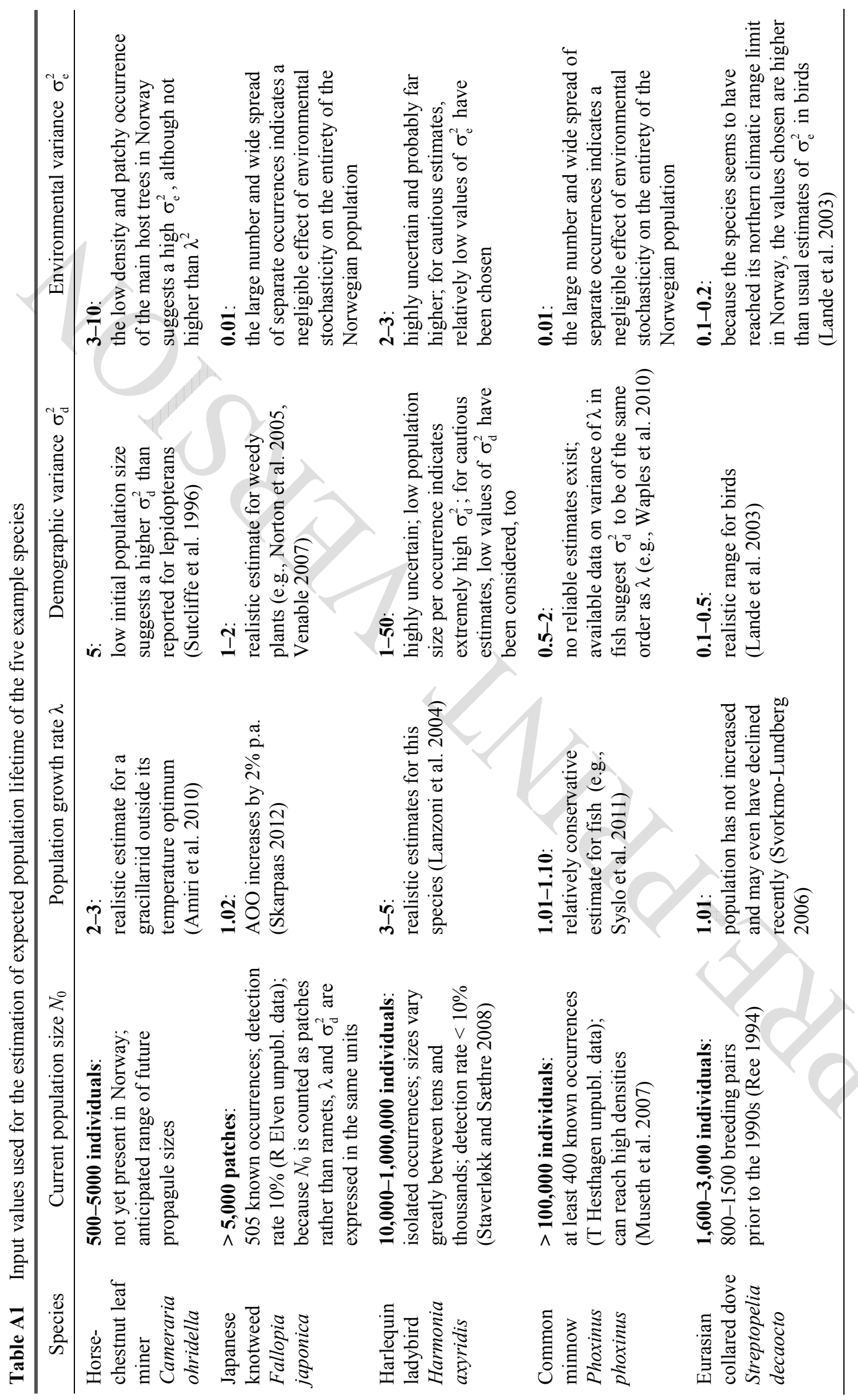

